Proceedings

\title{
Brine Shrimp Lethality Assay of the Aqueous and Ethanolic Extracts of the Selected Species of Medicinal Plants ${ }^{+}$
}

\author{
Sandeep Waghulde ${ }^{1, *}$, Mohan K. Kale ${ }^{1}$ and VijayR. Patil ${ }^{2}$ \\ 1 Konkan Gyanpeeth Rahul Dharkar College of Pharmacy and Research Institute, Karjat, \\ Raigad 410201, India; kalemkpharm@gmail.com \\ 2 Hon'ble Loksevak Madhukarrao Chaudhari College of Pharmacy, Faizpur, Jalgaon 425503, India; \\ drvrpatil@gmail.com \\ * Correspondence: sandeepwaghulde@yahoo.com \\ + Presented at the 23rd International Electronic Conference on Synthetic Organic Chemistry, \\ 15 November-15 December 2019; Available online: https://ecsoc-23.sciforum.net/.
}

Published: 19 November 2019

\begin{abstract}
The present study was conducted to test for in vivo Brine Shrimp Lethality Assay (BSLA) of the Aqueous and ethanolic extracts of Annona reticulata with Allium fistolisum and Brassica oleraceaeand correlate cytotoxicity results with known pharmacological activities of the plants. Cytotoxicity was evaluated in terms of $\mathrm{LC}_{50}$ (lethality concentration). Ten nauplii were added into three replicates of each concentration of the plant extract. After $24 \mathrm{~h}$ the surviving brine shrimp larvae were counted and LC 50 was assessed. Results showed that the extracts of Annona reticulata with Allium fistolisumand Brassica oleraceaewere potent against the brine shrimp when compared alone with combined extracts. It indicated that bioactive components are present in these plants that could be accounted for its pharmacological effects. Thus, the results support the uses of these plant species in traditional medicine.
\end{abstract}

Keywords: brine shrimp lethality assay; Annona reticulate; Allium fistolisum and Brassica oleraceae; LC50; potent; cytotoxicity

\section{Introduction}

The crushed leaves of A. reticulata are used as poultice on boils, ulcers and abscesses and leaf decoction is used as vermifuge. The tree is not especially attractive. It is erect, with a rounded or spreading crown and trunk 10 to 14 in $(25-35 \mathrm{~cm})$ thick. Height ranges from 15 to $35 \mathrm{ft}(4.5-10 \mathrm{~m})$. The ill-smelling leaves are deciduous, alternate, oblong or narrow-lanceolate, 4 to 8 in $(10-20 \mathrm{~cm})$ long, $3 / 4$ to 2 in $(2-5 \mathrm{~cm})$ wide, with conspicuous veins.

Taking all the above concerns into account, we conducted this study to find out more about A. reticulata leaves. We studied the antioxidant effects with presence of such phytochemical constituents as equivalent to standards in different extracts, the cytotoxic effect, and hence antitumor effect.

Spring Onion (Allium fistolisum) is a promising source of bioactive moieties such as quercetin and flavonoids that exhibited various biological activities such as anticancer, antioxidant, antimicrobial [1] antiplatelet, antidiabetic, anti-inflammatory, and antiasthmatic effects, antithrombotic, antihyperlipidemic, and antihypertensive [2-4]. These biological activities are performed due to the presence of high content of sulfur compounds and flavonoids [5].

Bioactive compounds of spring onion suppress the inducible nitric oxide synthase (iNOS), cyclooxygenase-2 (COX-2), and inhibit the development of different cellular markers, which are 
responsible for tumor apoptosis, proliferation, the development of new blood vessels (angiogenesis) and tumor invasion [6]. These compounds also lower the risk of gastrointestinal tract cancer through repressing Helicobacter pylori and other bacterial action, and lowering the endogenous arrangement of compounds cancer-causing N-nitroso [7].

Cruciferous vegetables are one of the dominant food crops which have high vitamin $C$, soluble fibre and contain multiple nutrients and phytochemicals with potential anticancer properties. Brassica oleracea (Cauliflower) belongs to the family Brassicaceae is an annual plant that reproduces by seed. The plant have leaves which are more divided and petiolate. The main head consists of clusters of fully differentiated flower buds which are less densely arranged with longer peduncles. It is an annual herb reaching $400 \mathrm{~mm}$ during vegetative stage and 1-2 $\mathrm{m}$ at the end of flowering [8]. Cauliflower is low in fat, but high in dietary fibre, potassium, folate, water and vitamin and possesses a high nutritional density. Cauliflower contains several phytochemicals which are beneficial to human health [9]. It has antimicrobial [10,11] and antioxidant [12] activities. The present study was undertaken to investigate the cytotoxic and thrombolytic activity of flower extract of the plant.

Red cabbage is the member of Brassicaceae family. It is a cool season cruciferous vegetable. Red cabbage (Brassica oleracea var. capitata f. rubra) is type of cabbage, also well-known as purple cabbage, blue kraut, or red kraut and is widespread in the Mediterranean region [13]. Red Cabbage is a herbaceous, biennial, dicotyledonous flowering plant. Its leaves are red or purple in colour and are normally consumed as coleslaw, salad and beverage [14].

The principle "bioactive components of red cabbage are isothiocyanates, vitamins A, B, C and anthocyanins" [15-17]. Anthocynanins, a natural pigment present in Red cabbage, were found to have the strongest antioxidant power of 150 flavonoids [18]. They are water soluble pigments it can be red, blue or purple depending on the $\mathrm{pH}$. They are dominant antioxidants that have antiinflammatory properties which help to protect cells. Along with the "substances that seem to be responsible for the biological activities of red cabbage, are polyphenols" [19]. "Polyphenols are antioxidants that are helpful in reversing the problems caused by oxidative stress to the walls of arteries. Create a heart healthy environment by curbing the oxidation of LDL cholesterol and they help to relieve chronic pain, as seen in condition like rheumatoid arthritis, due to their antiinflammatory properties."

\section{Materials and Methods}

\subsection{Plant Materials}

Random samples of spring onion samples were collected from local retail markets of Karjat, Maharashtra, India. Samples were then washed thoroughly with tap water to remove dust and dirt particles. Afterwards, the outer skin of the samples were removed and then divided into small sections and they were placed into hot oven, for drying at $40^{\circ} \mathrm{C}$. The dried samples were grinded into fine powder by using a grinder and then were put in glass bottles [20]. Plant materials were authenticated at "The Blatter Herbarium" - St. Xavier's College, Mumbai.

Ten grams of spring onion's leaves or bulb were soaked in $100 \mathrm{~mL}$ of methanol and water, respectively. The prepared samples were shake using orbital shaker for $7 \mathrm{~h}$ followed by centrifugation for $15 \mathrm{~min}$ at $7000 \mathrm{rpm}$. The extracts were then filtered using vacuum filtration assembly. The extracts were assessed Brine shrimp lethality bioassay

Red cabbage leaves were shade dried followed by hot air oven drying at $50^{\circ}$ centigrade and then ground to a fine powder and stored in air tight container for the analysis. Fresh red cabbage leaves were grinded in the mixer for the collection of juice.

The coarse powder and juice of red cabbage was extracted with methanol and water. The extracts of red cabbage powder and juice were collected separately and filtered using Whatman filter paper. All the extracts were concentrated and the excessive solvents were evaporated under vacuum. 


\subsection{Brine Shrimp Lethality Bioassay}

The extracts, fractions and pure isolated compounds were routinely evaluated in a test for lethality to brine shrimp larvae (Figure 1). Toxicities of compounds were tested at 1, 10, 100, and $1000 \mathrm{ppm}$ in $10 \mathrm{~mL}$ sea-water solutions with $1 \%$ DMSO $(v / v)$. Ten, nauplii were used in each test and survivors counted after $24 \mathrm{~h}$ (Figure 2). Three replications were used for each concentration. The blank control is conducted with Distilled water. The lethal concentration for $50 \%$ mortality after $24 \mathrm{~h}$ of exposure, the chronic LC 50 was determined using the probit method, as the measure of toxicity of the extract or fractions. LC 50 values greater than $1000 \mathrm{ppm}$ for plant extracts were considered inactive.

The brine shrimp lethality assay (BSLA) is a simple and inexpensive bioassay used for testing the efficacy of phytochemical present in the plant extracts. The present study determined that the extent of lethality was directly proportional to the concentration of the extract. After $24 \mathrm{~h}$ of observation all the shrimp were survived in the control. Even though, maximum mortalities were observed upto a concentration of $1000 \mu \mathrm{g} / \mathrm{mL}$ and least mortality at $1 \mu \mathrm{g} / \mathrm{mL}$ concentrations. It was observed that in higher concentration of treatment extracts, the shrimps were start dying only after $8 \mathrm{~h}$ and after $24 \mathrm{~h}$ all the shrimps died. The lethality concentration (LC50) was calculated by using probit analysis. The $\mathrm{LC}_{50}$ (median lethal concentration) values were calculated by using the regression line obtained by plotting the concentration against the death percentage on a probit scale.

\subsection{Significance of Brine Shrimp Lethality Assay of the Plant}

The evolution of the toxic action of plant extracts is indispensable to consider a treatment safe; it enables the definition of the intrinsic toxicity of the plant, and the effects of acute overdose [10], a cheap and general bioassay that appears capable of detecting a spectrum of bioactivity present in crude extract is the brine shrimp lethality test. The lethality of the test sample in a simple zoological organism like the brine shrimp (Artemia salina) has been utilised by many researchers and has proven to be a useful tool in screening various chemical compounds found in various bioactivities. After $24 \mathrm{~h}$ the number of survival of nauplii was counted and percentage of mortality was determined using the equation: [20-23]

$$
\% \text { mortality }=(\text { no. of dead nauplii/initial no. of live nauplli }) \times 100 \text {. }
$$

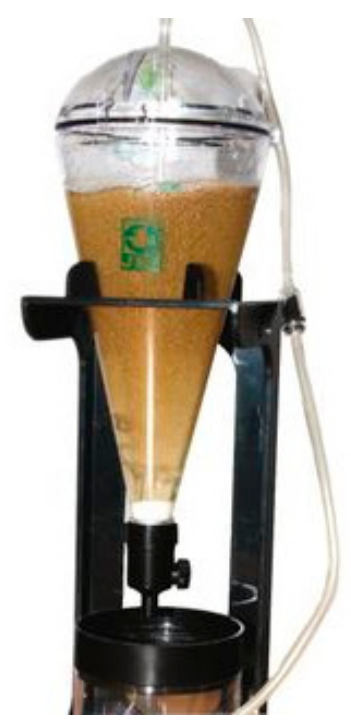

Figure 1. Breeding for Brine shrimps. 


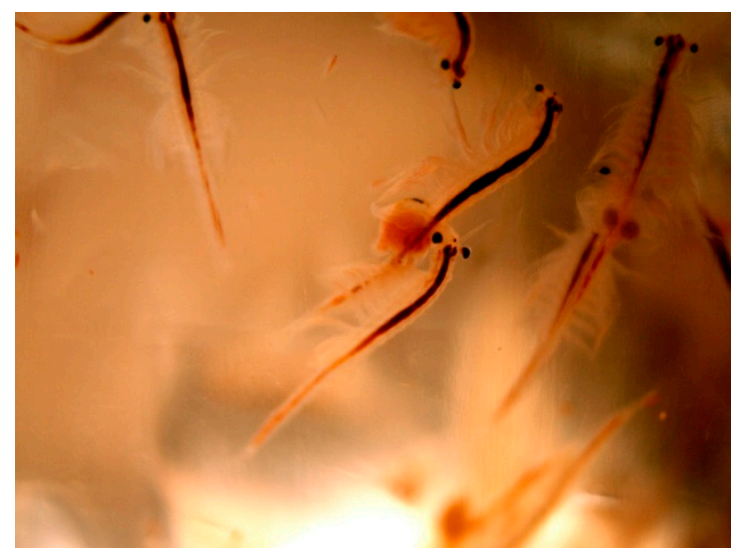

Figure 2. Fully grown Brine shrimps.

\section{Result and Discussion}

The brine shrimp lethality assay (BSLA) is a simple and inexpensive bioassay used for testing the efficacy of phytochemical present in the plant extracts. The present study determined that the extent of lethality was directly proportional to the concentration of the extract. After $24 \mathrm{~h}$ of observation all the shrimp were survived in the control. Even though, maximum mortalities were observed at a concentration of $1000 \mu \mathrm{g} / \mathrm{mL}$ and least mortality at $10 \mu \mathrm{g} / \mathrm{mL}$ concentrations. It was observed that in higher concentration of treatment extracts, the shrimps were start dying only after 8 $\mathrm{h}$ and after $24 \mathrm{~h}$ all the shrimps died.

The result on the lethality of Alcoholic and aqueous extract of Allium fistolisum on brine shrimps

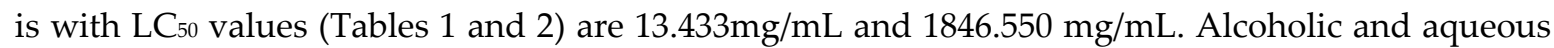
extract Brassica oleraceae was recorded LC 50 values of 10.818 and $64.839 \mathrm{mg} / \mathrm{mL}$ against brine shrimps. The presence of alkaloids, tannins, and flavonoids could be accounted for its cytotoxic properties. Therefore, combined alcoholic extracts and aqueous extracts of Allium fistolisum and Annona reticulata recorded LC 50 values of 0.500 and $284.674 \mathrm{mg} / \mathrm{mL}$ respectively. In the other hand, studies have shown that the extracts of Alcoholic and aqueous extract of Annona reticulata and Brassica oleraceae extracts exhibited LC 50 values of 28.287 and $129.025 \mathrm{mg} / \mathrm{mL}$ which are selective cytotoxicity against several cancer cell lines. Thus, the results shows Alcoholic and aqueous extract of Annona reticulate, Allium fistolisum and Brassica oleraceae exhibited cytotoxic activity support its use in traditional medicine. 
Table 1. \% Mortality of shrimp nauplii after treating with Alcoholic and aqueous extract of selected plants.

\begin{tabular}{|c|c|c|c|c|c|c|c|c|}
\hline \multirow[t]{2}{*}{ Plant Extracts } & \multirow{2}{*}{$\begin{array}{c}\text { Concentration } \\
\text { (ppm or } \\
\mu \mathrm{g} / \mathrm{mL})\end{array}$} & \multicolumn{3}{|c|}{$\begin{array}{c}\text { Number of Surviving Nauplii } \\
\text { (after } 24 \text { h) }\end{array}$} & \multirow{2}{*}{$\begin{array}{c}\text { Total Number of Nauplii } \\
\text { Survivors }\end{array}$} & \multirow{2}{*}{$\begin{array}{c}\% \\
\text { Mortality }\end{array}$} & \multirow{2}{*}{$\begin{array}{c}\mathrm{LC}_{50} \\
(\mu \mathrm{g} / \mathrm{mL})\end{array}$} & \multirow[t]{2}{*}{ Graph } \\
\hline & & T1 & T2 & T3 & & & & \\
\hline \multirow{4}{*}{$\begin{array}{c}\text { Control } \\
\text { (Distilled water) }\end{array}$} & 1 & 10 & 10 & 9 & 29 & $96 \%$ & \multirow{4}{*}{372.846} & \multirow{4}{*}{ Figure 3} \\
\hline & 10 & 10 & 9 & 10 & 29 & $96 \%$ & & \\
\hline & 100 & 8 & 10 & 10 & 28 & $93 \%$ & & \\
\hline & 1000 & 10 & 10 & 10 & 30 & $100 \%$ & & \\
\hline \multirow{4}{*}{$\begin{array}{c}\text { Standard } \\
\text { (Vincristine sulphate) }\end{array}$} & 1 & 0 & 0 & 0 & 0 & $100 \%$ & \multirow{4}{*}{0.00} & \multirow{4}{*}{---- } \\
\hline & 10 & 0 & 0 & 0 & 0 & $100 \%$ & & \\
\hline & 100 & 0 & 0 & 0 & 0 & $100 \%$ & & \\
\hline & 1000 & 0 & 0 & 0 & 0 & $100 \%$ & & \\
\hline \multirow{4}{*}{$\begin{array}{l}\text { Annona reticulata } \\
\text { (Alcoholic Extract) }\end{array}$} & 1 & 10 & 10 & 10 & 30 & $0 \%$ & \multirow{4}{*}{24.162} & \multirow{4}{*}{ Figure 4} \\
\hline & 10 & 6 & 8 & 7 & 22 & $73 \%$ & & \\
\hline & 100 & 3 & 2 & 3 & 8 & $27 \%$ & & \\
\hline & 1000 & 1 & 0 & 0 & 1 & $3.3 \%$ & & \\
\hline \multirow{4}{*}{$\begin{array}{l}\text { Annona reticulata } \\
\text { (Aqueous Extract) }\end{array}$} & 1 & 10 & 10 & 10 & 30 & $0 \%$ & \multirow{4}{*}{18.923} & \multirow{4}{*}{ Figure 5} \\
\hline & 10 & 8 & 6 & 6 & 20 & $66.6 \%$ & & \\
\hline & 100 & 3 & 2 & 5 & 10 & $33.3 \%$ & & \\
\hline & 1000 & 0 & 1 & 0 & 1 & $3.3 \%$ & & \\
\hline \multirow{4}{*}{$\begin{array}{l}\text { Allium fistolisum } \\
\text { (Alcoholic Extract) }\end{array}$} & 1 & 1 & 0 & 1 & 2 & $7 \%$ & \multirow{4}{*}{13.433} & \multirow{4}{*}{ Figure 6} \\
\hline & 10 & 4 & 3 & 4 & 11 & $37 \%$ & & \\
\hline & 100 & 7 & 8 & 7 & 22 & $73 \%$ & & \\
\hline & 1000 & 9 & 8 & 8 & 25 & $83 \%$ & & \\
\hline \multirow{4}{*}{ Allium fistolisum(Aqueous Extract) } & 1 & 1 & 0 & 1 & 2 & $7 \%$ & \multirow{4}{*}{1846.550} & \multirow{4}{*}{ Figure 7} \\
\hline & 10 & 2 & 3 & 4 & 9 & $30 \%$ & & \\
\hline & 100 & 2 & 2 & 6 & 10 & $33 \%$ & & \\
\hline & 1000 & 6 & 7 & 8 & 16 & $53 \%$ & & \\
\hline \multirow{4}{*}{$\begin{array}{l}\text { Allium fistolisum and Annona } \\
\text { reticulata } \\
\text { (1:1) Alcoholic extracts }\end{array}$} & 1 & 9 & 9 & 10 & 29 & $1 \%$ & \multirow{4}{*}{0.500} & \multirow{4}{*}{ Figure 8} \\
\hline & 10 & 5 & 4 & 5 & 14 & $16 \%$ & & \\
\hline & 100 & 3 & 2 & 2 & 7 & $23 \%$ & & \\
\hline & 1000 & 1 & 0 & 1 & 2 & $28 \%$ & & \\
\hline & 1 & 1 & 0 & 1 & 5 & $17 \%$ & & \\
\hline Allium fistolisum and Annona & 10 & 2 & 3 & 4 & 12 & $40 \%$ & & \\
\hline $\begin{array}{l}\text { reticulata } \\
\text { (1.1) Agups extract }\end{array}$ & 100 & 2 & 2 & 6 & 13 & $43 \%$ & 284.674 & Figure 9 \\
\hline (1:1) Aqueous extract & 1000 & 6 & 7 & 8 & 16 & $53 \%$ & & \\
\hline
\end{tabular}




\begin{tabular}{|c|c|c|c|c|c|c|c|c|}
\hline \multirow{4}{*}{$\begin{array}{l}\text { Brassica oleraceae } \\
\text { (Alcoholic Extract) }\end{array}$} & 1 & 5 & 7 & 7 & 19 & $37 \%$ & \multirow{4}{*}{10.818} & \multirow{4}{*}{$\begin{array}{l}\text { Figure } \\
10\end{array}$} \\
\hline & 10 & 4 & 4 & 3 & 11 & $63 \%$ & & \\
\hline & 100 & 0 & 0 & 0 & 0 & $100 \%$ & & \\
\hline & 1000 & 0 & 0 & 0 & 0 & $100 \%$ & & \\
\hline \multirow{4}{*}{$\begin{array}{l}\text { Brassica oleraceae } \\
\text { (Aqueous Extract) }\end{array}$} & 1 & 1 & 0 & 1 & 2 & $7 \%$ & \multirow{4}{*}{64.839} & \multirow{4}{*}{$\begin{array}{c}\text { Figure } \\
11\end{array}$} \\
\hline & 10 & 2 & 1 & 1 & 4 & $13 \%$ & & \\
\hline & 100 & 5 & 5 & 4 & 14 & $47 \%$ & & \\
\hline & 1000 & 7 & 8 & 6 & 21 & $70 \%$ & & \\
\hline \multirow{4}{*}{$\begin{array}{c}\text { Brassica oleraceaeand Annona } \\
\text { reticulata } \\
\text { (1:1) Alcoholic extracts }\end{array}$} & 1 & 1 & 0 & 1 & 2 & $7 \%$ & \multirow{4}{*}{28.287} & \multirow{4}{*}{$\begin{array}{c}\text { Figure } \\
12\end{array}$} \\
\hline & 10 & 2 & 3 & 4 & 9 & $30 \%$ & & \\
\hline & 100 & 5 & 7 & 6 & 18 & $60 \%$ & & \\
\hline & 1000 & 9 & 7 & 8 & 24 & $80 \%$ & & \\
\hline \multirow{4}{*}{$\begin{array}{c}\text { Brassica oleraceaeand Annona } \\
\text { reticulata } \\
\text { (1:1) Aqueous extract }\end{array}$} & 1 & 7 & 9 & 8 & 7 & 20 & \multirow{4}{*}{129.025} & \multirow{4}{*}{$\begin{array}{c}\text { Figure } \\
13\end{array}$} \\
\hline & 10 & 7 & 6 & 7 & 7 & 33 & & \\
\hline & 100 & 4 & 5 & 5 & 4 & 53 & & \\
\hline & 1000 & 0 & 0 & 0 & 0 & 100 & & \\
\hline
\end{tabular}




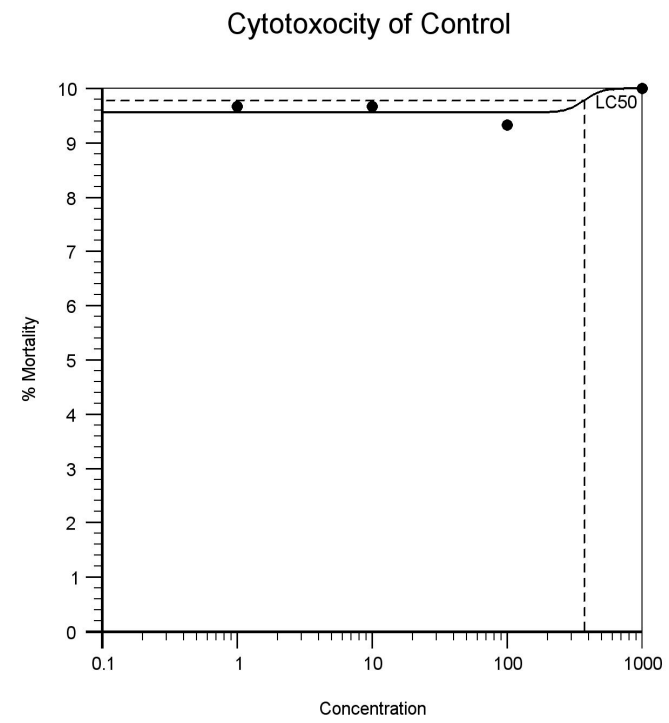

Figure 3. Cytotoxicity of Control.

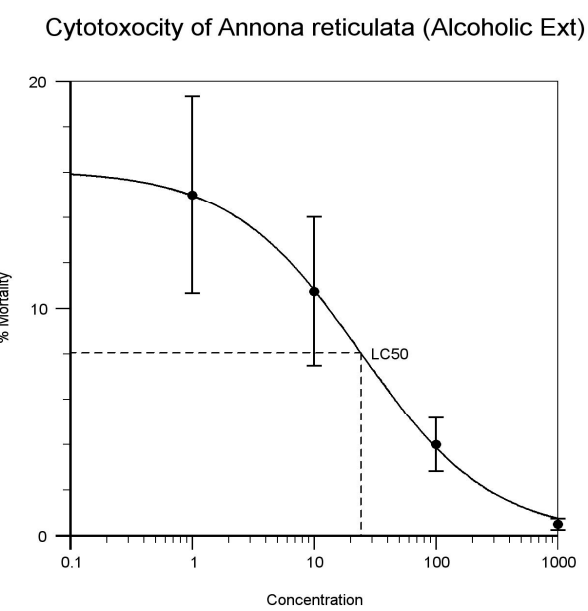

Figure 4. Cytotoxicity of Annona reticulate (Alcoholic Extract).

Cytotoxocity of Annona reticulata (Aqueous Ext.)

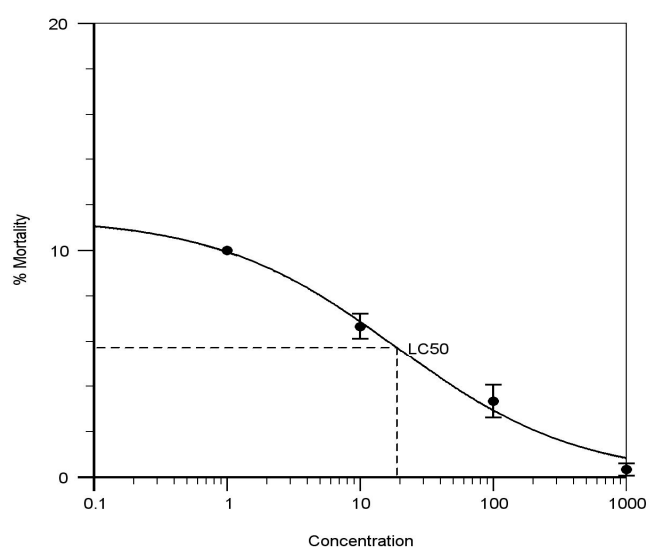

Figure 5. Cytotoxicity of Annona reticulate (Aqueous Extract). 
Cytotoxicity of Annona fistolisum (Alcoholic Ext.)

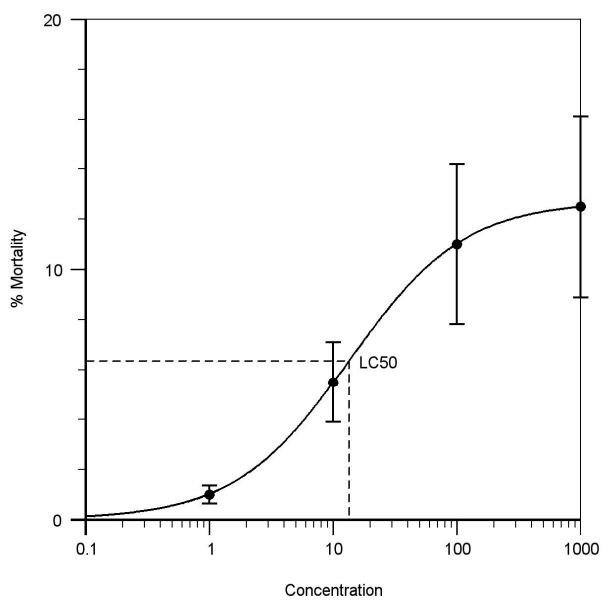

Figure 6. Cytotoxicity of Annona fistolisum. (Alcoholic Extract).

Cytotoxicity of Annona fistolisum (Aqueous Ext.)

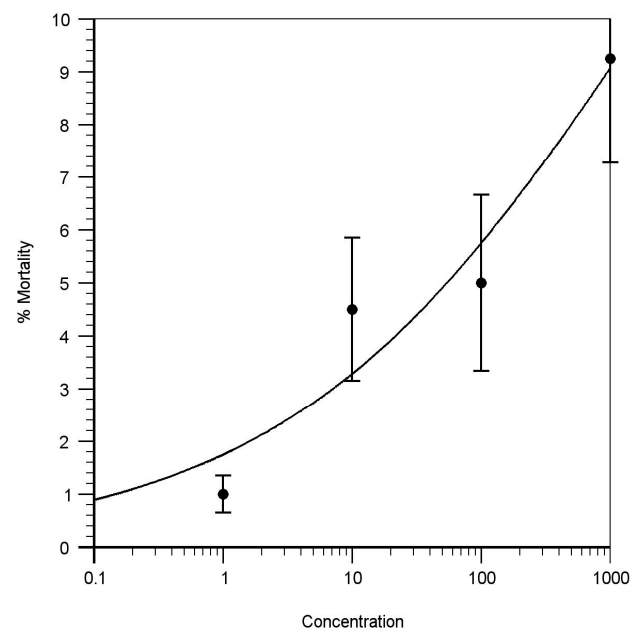

Figure 7. Cytotoxicity of Annona fistolisum. (Aqueous Extract).

Cytotoxicity of A. fistolisum \& A. reticulata Alc

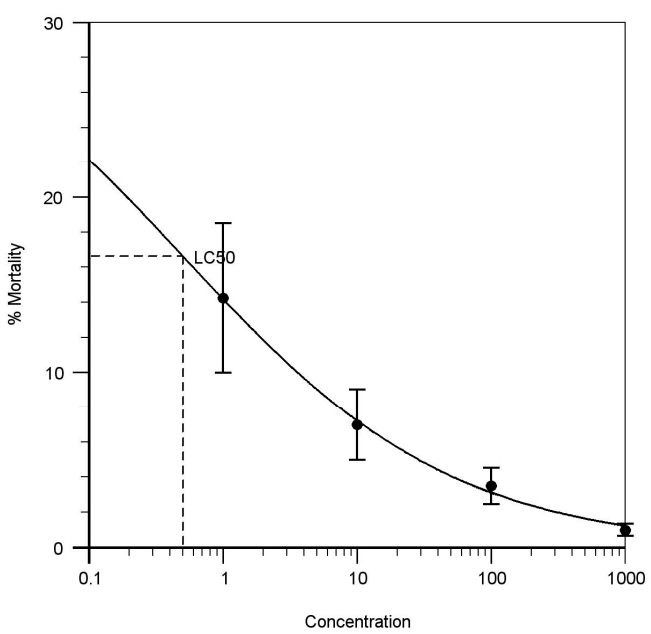

Figure 8. Cytotoxicity of Allium fistolisum and Annona reticulata. (1:1) Alcoholic extracts. 
Cytotoxicity of $A$. fistolisum \& A. reticulata Aq.

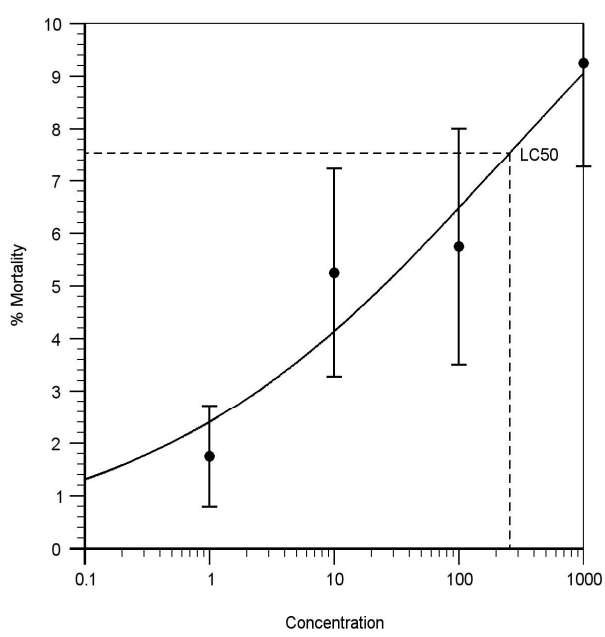

Figure 9. Cytotoxicity of Allium fistolisum and Annona reticulata (1:1) Aqueous extract.

Cytotoxicity of Brassica oleraceae (Alc Ext.)

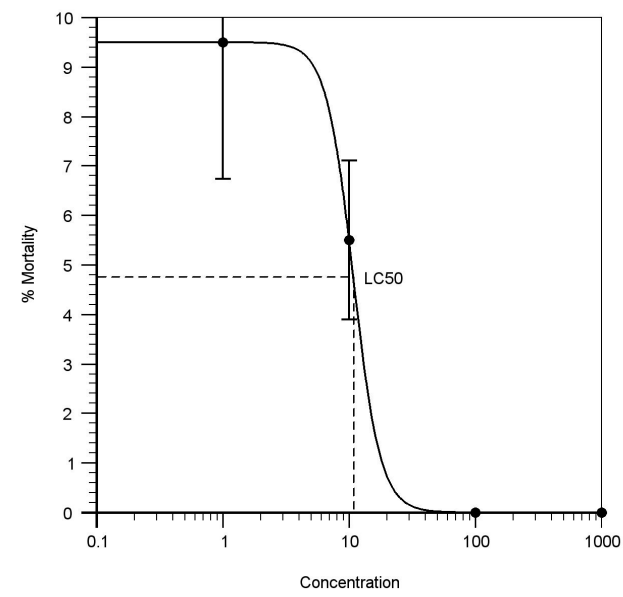

Figure 10. Cytotoxicity of Brassica oleraceae (Alcoholic extract).

Cytotoxicity of Brassica oleraceae (Aq Ext.)

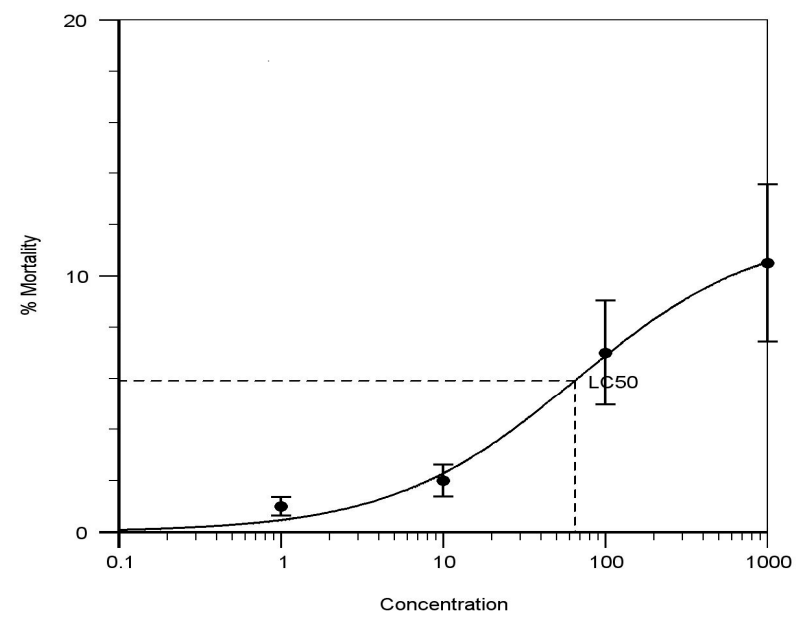

Figure 11. Cytotoxicity of Brassica Oleraceae (Aqueous extract). 
Cytotoxicity of B. oleraceae \& A. reticulata Alc.

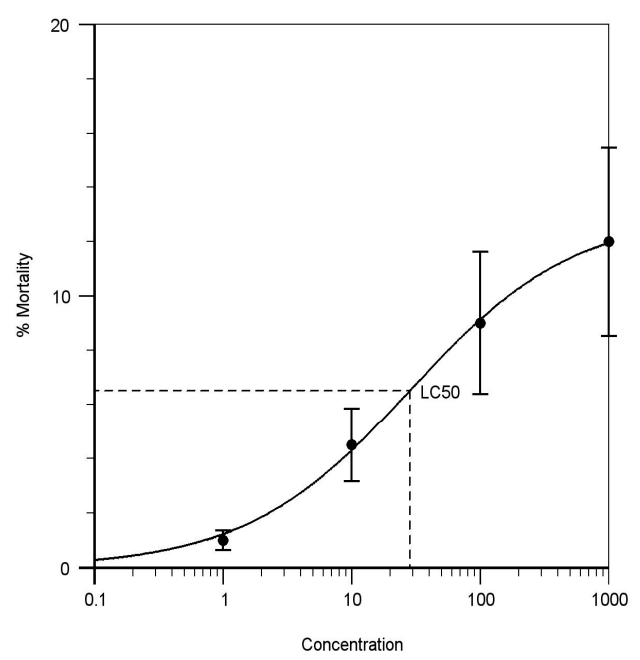

Figure 12. Cytotoxicity of Brassica oleraceae and Annona reticulata (1:1) Alcoholic extracts.

Cytotoxicity of B. oleraceae \& A. reticulata Aq.

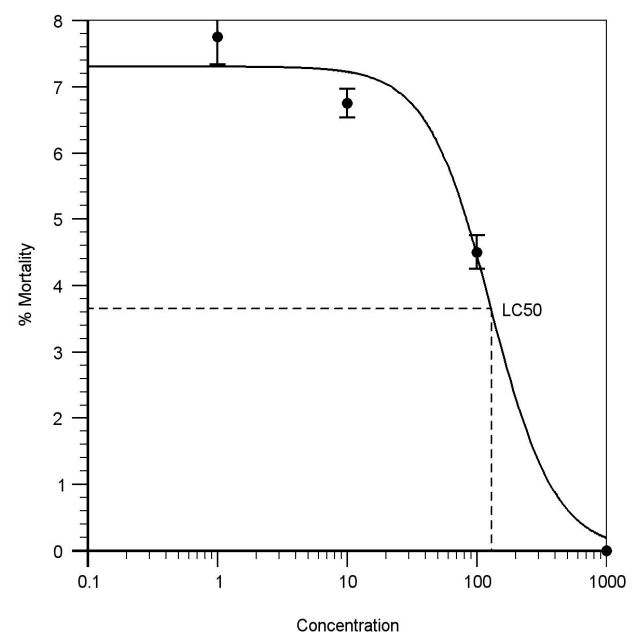

Figure 13. Cytotoxicity of Brassica oleraceae and Annona reticulate (1:1) Aqueous extract.

Table 2. Summary of Plant extracts and their LC 50.

\section{Plant Extracts}

Control (Distilled water)

Standard (Vincristine sulphate)

Annona reticulata (Alcoholic extracts)

Annona reticulata (Aqueous extract)

Allium fistolisum (Alcoholic extracts)

Allium fistolisum (Aqueous extract)

Brassica oleraceae (Alcoholic extracts)

Brassica oleraceae (Aqueous extract)
$\mathrm{LC}_{50}(\mathrm{mg} / \mathrm{mL})$

372.846

0.00

24.162

18.923

13.433

1846.550

10.818

64.839

0.500

284.674

28.287

129.025 


\section{Conclusions}

Alcoholicand aqueous extract of Allium fistolisum and Brassica oleraceaeexhibited cytotoxic activity against the brine shrimp and considered as containing active or potent components. The ethnopharmacological activities of these plant species are due to the different bioactive compounds present in these plants. Although, BSLA is inadequate in determining the mechanism of action of the bioactive substances in the plant, it is very useful by providing a preliminary screening that can be supported by a more specific bioassay, once the active compound has been isolated. Thus, some useful drugs of therapeutic importance may develop out of the research work.

Acknowledgments: The authors are very much thankful to Mohan kale, Principal, Bharat Tekade, HOD, Pharmacy and Amol Chadekar, HOD of the Pharmacology Department KGRDCP \& RI, Karjat.

\section{References}

1. Lee, Y.R.; Hwang, I.G.; Woo, K.S.; Kim, D.J.; Hong, J.T.; Jeong, H.S. Antioxidative activities of the ethyl acetate fraction from heated onion (Alliumcepa). Food Sci. Biotechnol. 2007, 16, 1041-1045.

2. Osmont, K.S.; Arnt, C.R.; Goldman, I.L. Temporal aspects of onion-induced antiplatelet activity. Plant Foods Hum. Nutr. 2003, 58, 27-40.

3. Kelkar, S.M.; Kaklij, G.S.; Bapat, V.A. Determination of antidiabetic activity in Allium cepa (onion) tissue cultures. Indian J. Biochem. Biophys. 2001, 38, 277-279.

4. Mukherjee, P.K.; Kumar, V.; Houghton, P.J. Screening of Indian medicinal plants for acetyl cholinesterase inhibitory activity. Phytother. Res. 2007, 21, 1142-1145.

5. Sue, D.W.; Sue, D. Counseling the Culturally Different; Wiley: New York, NY, USA, 1999.

6. Arulselvan, P.; Wen, C.C.; Lan, C.W.; Chen, Y.H.; Wei, W.C. Dietary Administration of Scallion Extract Effectively Inhibits Colorectal Tumor Growth: Cellular and Molecular Mechanisms in Mice. PLoS ONE 2012, 7, e44658.

7. Nicastro, H.L.; Ross, S.A.; Milner, J.A. Garlicand onions: their cancer prevention properties. Cancer Prev. Res. 2015, 8, 181-189.

8. Dixon, G.R. Vegetable Brassicas and Related Crucifers; CABI Publishing: London, UK, 2007.

9. Bastin, S. Vegetables for Wellness Kentucky Broccoli. Agriculture and Natural Resources, 1 May 2001.

10. Survay, S.N.; Kumar, B.; Jang, M.; Yoon, D.Y.; Jung, Y.S.; Yang, D.C.; Park, S.W. Two novel bioactive glucosinolates from Broccoli (Brassica oleracea Lvar. italica) florets. Bioorg. Med. Chem. Lett. 2012, 22, 5555-5558.

11. Jaiswal, A.K.; Rajauria, A.G.; Gupta, S. Phenolic composition, antioxidant capacity and antibacterial activity of selected Irish Brassica vegetables. Nat. Prod. Commun. 2011, 6, 1299-1304.

12. Mahn, A.; Reyes, A. An overview of health promoting compounds of broccoli (Brassica oleraceavar. italica) and the effect of processing. Food Sci. Technol. Int. 2011, 18, 503-514.

13. Lynn, A.; Collins, A.; Fuller, Z.; Hillman, K.; Rateliffe, B. Cruciferous vegetables and colorectal cancer. Proc. Nutr. Soc. 2006, 65, 135-144.

14. El-Motalebel-Mowafy, M.A. Treatment Effect of Red Cabbage and Cysteine against Paracetamol Induced Hepatotoxicity in Experimental Rats. J. Appl. Sci. Res. 2012, 8, 5852-5859.

15. Fowke, J.H.; Chung, F.L.; Jin, F.; Qi, D.; Cai, Q.; Conaway, C.; Cheng, J.R.; Shu, X.O.; Gao, Y.T.; Zheng, W. Urinary isothiocynate level, Brassica, and human breast cancer. Cancer Res. 2003, 63, 3980-3986.

16. Repetto, M.G.; Llesuy, S.F. Antioxidant properties of natural compounds used in popular medicine for gastric ulcers. Braz. J. Med. Biol. Res. 2002, 35, 523-534.

17. Jagdish Singh, A.K.; Upadhyay, A.; Bahadhur, B.; Singh, B.; Singh, K.P.; Mathura Rai, A.K. Antioxidant phytochemical in cabbage (Brassica Oleracea L. var. capitata). Sci. Hortic. 2006, 108, $233-237$.

18. Sterling, M. Got anthocyanins. They plant pigments are more than coloring agents for fruits juices, wine and other beverages: They also contain an arry of health-promoting benefits. Nutr. Sci. News 2000, 5, 231-234.

19. Hassimotto, N.M.; Genovese, M.I.; Lajolo, F.M. Antioxidant activity of dietary fruits, vegetables, and commercial frozen fruits pulps. J. Agric. Food Chem. 2005, 53, 2928-2935. 
20. Krishnaraju, A.V.; Rao, T.V.N.; Sundararaju, D.; Vanisree, M.; Tsay, H.S.; Subbaraju, G.V. Assessment of bioactivity of Indian medicinal plants using brine shrimp (Artemia salina) lethality assay. Int. J. Appl. Sci. Eng. 2005, 3, 125-134.

21. McLaughlin, J.; Chang, C.; Smith, D. Simple bench-top bioassays (brine shrimp and potato discs) for the discovery of plant antitumour compounds. In Proceedings of the 18th National Seminar and UNESCO Workshop on Natural Products, Kuala Lumpur, Malaysia, 20-25 September 1993.

22. Meyer, N.B.; Ferrigni, N.R.; Putnam, J.E.; Jacobsen, L.B.; Nichols, D.E.; McLaughlin, J.L. Brine Shrimp: A convenient general bioassay for active plant constituents. Planta Med. 1982, 45, 31-34.

23. Apu, A.; Muhit, M.; Tareq, S.; Pathan, A.; Jamaluddin, A.; Ahmed, M. Antimicrobial activity and brine shrimp lethality bioassay of the leaves extract of Dillenia indica linn. J. Young Pharm. 2010, 2, 50-53.

(C) 2020 by the authors. Licensee MDPI, Basel, Switzerland. This article is an open access article distributed under the terms and conditions of the Creative Commons Attribution (CC BY) license (http://creativecommons.org/licenses/by/4.0/). 